\title{
REFLEXIONES SOBRE EL TRASFONDO POLÍTICO EN EL JUICIO CONTRA SÓCRATES
}

JuAn Pablo Ramis*

\section{RESUMEN}

El artículo, escrito desde la perspectiva de la historia de lasideas políticas, analiza la hipótesis de un trasfondo político en el juicio por impiedad efectuado contra Sócrates en 399 a. C. Para acceder a este objeto de estudio se cotejan las principales fuentes que abordan el tema y aquellas que contribuyen a contextual izarlo. Dada la ausencia de testimonios que descubran la voz de los querellantes, se procura reconstruir los argumentos esgrimidos por los mismos durante el proceso. Previamente, se realiza una breve alusión al denominado "problema socrático" y se intenta un acercamiento a la actitud política de Sócrates.

Palabras claves: Sócrates, juicio, trasfondo político.

\section{ABSTRACT}

This paper, written from the perspective of the History of Political Ideas, analyses the hypothesis of a political background in the trial for impiety held against Socrates in 399 BC. The various existing sources that deal with the topic and those that contribute to put it into context are examined in order to accede to this object of study. Given the lack of testimonies that could reveal the voice of the complainants, the intention is to rebuild their arguments wielded during the trial. Initially, a brief allusion to the so-called "Socratic problem" is given, as well as an approach to the Socratic political attitude.

Keywords: Socrates, trial, political background.

Recibido: 21.03.2005. Aprobado: 18.05.2005.

* Magister en Historia de las I deas Políticas. Facultad de Filosofía y Letras de la Universidad Nacional de Cuyo (Mendoza, Argentina).E-mail: ramis@logos.uncu.edu.ar 


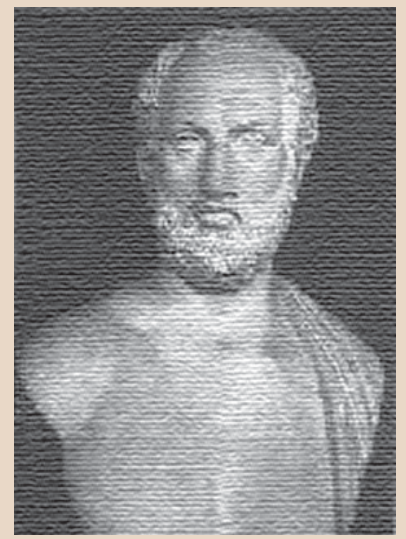

Tucídides

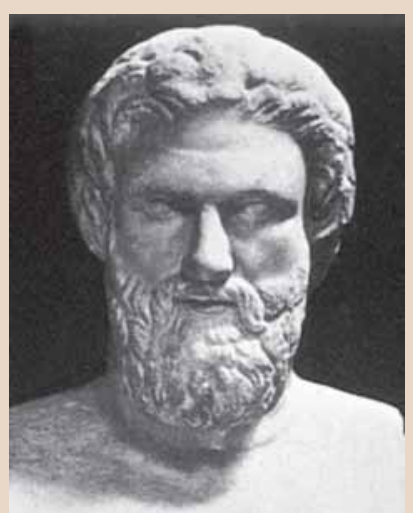

Aristófanes

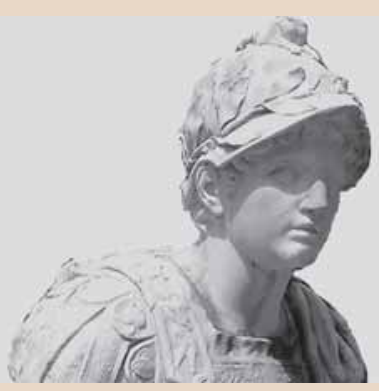

Plutarco
N EL 399 a. C., en el marco de la democracia ateniense restaurada, Sócrates fue acusado de asebeia (impiedad) y de corromper a los jóvenes. Tras el juicio realizado por el Tribunal de los Heliastas, el filósofo fue condenado a muerte. Este suceso histórico, documentado por diversostestimonios (Platón: A pología de Sócrates, Critón, Carta VII; Jenofonte: A pología deSócrates, M emorabilia; Diógenes Laercio: Vida delosfilósofos más ilustres) es, sin duda, el de mayor trascendencia de una serie de acontecimientos que ponen en entredicho la parresía (libertad de expresión) de la democracia ateniense postulada por Pericles en su célebre Epitafio:

Y nos regimos liberalmente no sólo en lo relativo a los negocios públicos, sino también en lo que se refiere a las sospechas recíprocas sobre la vida diaria, no tomando a mal al prójimo que obre según su gusto, ni poniendo rostros llenos de reproche [...] (Tucídides II, 37).

Confirma el "liberalismo" enunciado en el discurso la atracción ejercida por Atenas sobre intelectuales de diferentes sitios, que veían en esta ciudad el ámbito propicio para exponer sus ideas. También atestigua la afirmación que Tucídides pone en boca de Pericles, la absoluta licencia con que Aristófanes se manifiesta en sus comedias sobre asuntos políticos, religiosos o éticos. Sin embargo, diversos personajes vieron coartada su libertad de pensamiento al poner en duda los principios religiosos tradicionales de los atenienses:

[...] Aspasia fue acusada del crimen de irreligión, siendo el poeta cómico Hermipo quien la perseguía [...] Diopites hizo también decreto para que denunciase a los que no creían en las cosas divinas, o hablaban en su enseñanza de los fenómenos celestes; en lo que, a causa deAnaxágoras, se procuraba sembrar sospechas contra Pericles (Plutarco: Vida de Pericles XXXII).

[Protágoras] empezó de estemodo: "D e los dioses no sabré decir si los hay o no los hay, pues son muchas las cosas que prohíben el saberlo, ya la obscuridad del asunto, ya la brevedad de la vida del hombre". Por este principio de su tratado lo desterraron los atenienses, y sus libros fueron recogidos de manos de quienes los poseían, y quemados en el foro a voz de pregonero (Diógenes Laercio X, Protágoras).

Como propone Plutarco, el verdadero blanco de los ataques contra estos individuos era Pericles ${ }^{1}$ y, tras las acusaciones de carácter religioso, había motivaciones estrictamente políticas. En este sentido, y en relación con el tema específico del presente estudio, pretendo analizar la hipótesis, sosteni-

\footnotetext{
${ }^{1}$ Aspasia era la mujer de Pericles, en tanto que el filósofo Anaxágoras y el sofista Protágoras pertenecían al círculo de intelectual es que rodeaban al estratega.
} 
da por diversos eruditos contemporáneos, de un trasfondo político en el juicio por irreligiosidad contra Sócrates. El método por seguir para dar una respuesta a un problema de tan difícil resolución será, fundamentalmente, el de cotejar las principales fuentes que tratan el tema.

Si bien el objetivo del artículo no es examinar la posición filosófica ni ético-política de Sócrates, es necesario quenos acerquemos a al gunas facetas desu figura a fin de aclarar, en primer lugar, las dificultades con las que nos enfrentamos a la hora de querer conocer ciertos aspectos de su historia; en segundo término, para poder comprender adecuadamentela índole del juicio que lo condenó a muerte.

\section{BREVE ANALISIS SOBRE LAS FUENTES PARA CONOCER A SOCRATES}

M ucho seha escrito acerca del denominado "problema socrático", sintetizado con humor por Joël al afirmar que se puede aplicar la frase "sólo sé que no sé nada" al estado dela cuestión sobre estepersonaje (citado en Eggers Lan, 1971: 7). El origen de la incertidumbre que rodea el conocimiento de Sócrates se encuentra en el hecho de que el filósofo no puso por escrito su magisterio y que, por lo tanto, debemos llegar a él a través de fuentes contrapuestas en la caracterización quehacen de su personalidad y su pensamiento². Si Platón lo describe como un hombre virtuoso e inteligente, el Sócrates de Jenofonte coincide con el de Platón en su entereza ética pero no en su capacidad de razonamiento, mientras que Aristófanes, en la comedia Las nubes (fuente primigenia desdeuna perspectiva temporal para conocer aSócrates), lo pinta como una persona también muy inteligente pero inescrupuloso en extremo.

En realidad, Aristófanes, a quien el Sócrates platónico reprocha haber distorsionado su imagen ${ }^{3}$, lo identifica con un sofista ${ }^{4}$, aunque nos presente una visión simplista de los sofistas: embaucadores quelucran con sus cono-

2“[...] ¿hasta qué punto es Platón una fuenteutilizable, quécrédito podemosotorgar al Sócrates de Jenofonte, al de los socráticos menores, al de Aristóteles, etc.? ¿Qué es lo que en los escritos de éstos (cuando queda alguno) representa el pensamiento propio de Sócrates? Es ésta una cuestión que opiniones autorizadas han declarado insoluble" (Sauvage, 1963: 27).

3 "Retomemos entonces desde el principio qué acusación es la que ha originado la imagen de mí, confiando en la cual, al parecer, Meleto me ha demandado con semejante cargo. Bien. Pero, ¿qué decían los que forjaron esa imagen falsa? Como si setratara de acusadores judiciales hay que leer su testimonio: 'Sócrates es culpable de indagar impertinentemente las cosas subterráneas y celestiales, y de hacer pasar por más fuerte el argumento más débil, y enseñar a otros estas mismas cosas'. Tal es, aproximadamentesu testimonio; $y$, en efecto, ustedes mismos han visto estas cosas en la comedia de Aristófanes: allí un tal Sócrates da vueltas diciendo que anda por los aires y decla rando muchas otras tonterías, de las cuales yo no sé nada, ni mucho ni poco" (Platón: A pología de Sócratesl, 19 b- c)

${ }^{4}$ Cabe señalar que esta identificación se da también en algunos autores contemporáneos. Ver, por ejemplo: Vanoyeke, 2000.

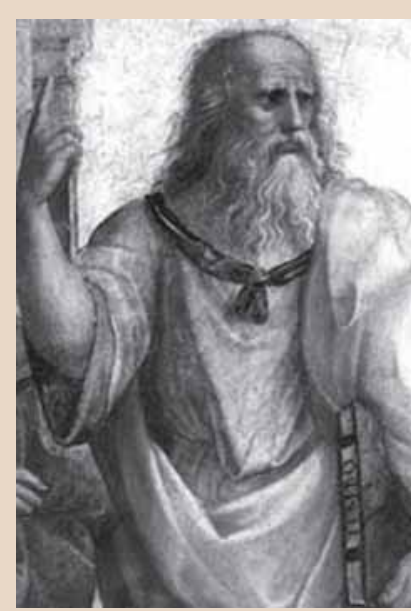

Platón 


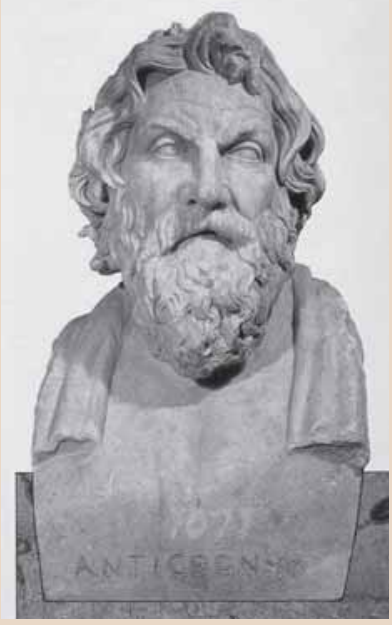

Antístenes

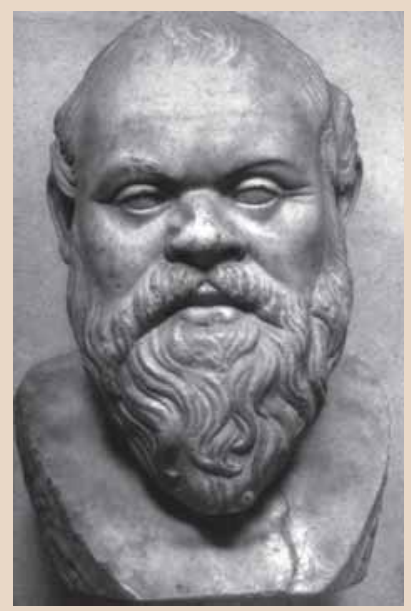

Sócrates cimientos. Seguramente la popularidad de Sócrates en el momento en que Aristófanes escenificó Las nubes ( 423 a. C.) movió a que el comediógrafo lo tomara como representante de un grupo de hombres que, según la percepción popular, llevaban una vida estrafalaria. En definitiva, la intención primaria de Aristófanes era hacer reír y, de acuerdo con Bergson, un medio adecuado para lograrlo consistía en burlarse de lo excéntrico ${ }^{5}$.

La imagen negativa de Sócrates que nos acerca Aristófanes es totalmente contrapuesta a la que nos brindan sus discípulos. Sin embargo, otro problema que debemos sortear es que los alumnos de Sócrates, después de las enseñanzas de su maestro, transitaron caminos muy diferentes entresí. Basta recordar los nombres de los filósofos Platón, Antístenes (fundador del cinismo) o Aristipo (iniciador del hedonismo), cada uno de los cuales se autoatribuyela posesión de lo esencial dela filosofía socrática. Por otra parte, contamos entre sus discípulos con el militar-historiador Jenofonte y con los políticos Alcibíades, Critias (uno de los integrantes de la Tiranía de los Treinta) o Q uerefonte (demócrata convencido), por mencionar algunos casos representativos.

Los especialistas se debaten en cuanto a adherir al sabio Sócrates platónico 0 al Sócrates jenofontiano, de rasgos menos el evados pero de carácter, aparentemente, más histórico. Seguir unilateralmente cualquiera de las dos visiones implica riesgos: los hermeneutas contemporáneos coinciden en advertir que Jenofonte escribió sobre Sócrates en una época tardía y que incorporó notas de su maestro que ya habían expuesto otros autores. Con respecto a Platón, el dilema es descubrir el límite entre sus ideas y las de Sócrates, personaje central de la mayoría de sus diálogos. Según Maier los diálogos socráticos "no perseguían en manera al guna la finalidad de exponer cómo el maestro difunto había hablado antaño, sino que más bien tenían el objeto de continuar la obra de Sócrates" (citado en Tovar, 1947: 28) ${ }^{6}$. Sin embargo, también existe consenso en advertir queen los diálogos platónicos juveniles (ente ellos A pología de Sócrates y Critón) el discípulo refleja los rasgos auténticos de su maestro, lo que no sucede en sus obras de madurez (como la República), en donde Sócrates se convierte en el portavoz de Platón.

A fin de resolver la difícil tarea de descubrir al Sócrates histórico, es necesario tener en cuenta una doble consideración metodológica: en primer término, pueden asumirse como verdaderamente socráticos los caracteres

5 “La risa es ante todo una corrección [...] La sociedad se venga por su medio de las libertades que con ella se han tomado" (Bergson, 1939: 215. Citado en Ramis, 2003: 139).

${ }^{6}$ En esta línea de pensamiento se ubica Rosen: "Platone se autocomprende come erede e continuatore dell 'opera di Socrate, e per questo in quasi tutti i suoi dial oghi egli fa di Socrateil suo portavoce ufficiale" (1999: 85). 
en los que coinciden las diferentes fuentes; a este paso, habría que sumar el siguientepropuesto por Eggers Lan: los rasgos con quese describea Sócrates y que sean opuestos a los del autor que nos transmite la información, pueden tomarse como realmente históricos (1971: 71) 7 .

\section{LA ACTITUD POLITICA DE SOCRATES}

Este es uno de los campos donde se ponen claramente de manifiesto las discrepancias interpretativas entre los críticos. Básicamente, las opiniones divergentes surgen a la hora de argüir sobre la postura de Sócrates frenteala democracia. Si bien son múltiples las respuestas propuestas al problema planteado, podemos agruparlas en tres principales:

- Sócrates asumió una posición de rechazo hacia la democraciå. Quienes respaldan esta tesis se basan en pasajes provenientes tanto de la pluma de Platón como de Jenofonte, en donde Sócrates se opone al sistema de sorteo y postula que, como en otras áreas, también la política debe ser dirigida por especialistas. A estos fundamentos agregan los siguientes: el origen aristocrático de buena parte desus seguidores, el acento que poneSócrates en la necesidad de que reine el orden en la polis y su reverencia hacia el dios Apolo, identificado con los sectores aristocráticos.

- Sócrates era un demócrata convencido ${ }^{9}$. Los autores que se suman a este postulado se apoyan en otros textos y explican de modo distinto aquellos en los que se basan los del primer grupo. Así, ven como factores democráticos el queSócrates consideraseel diálogo con hombres detoda clase como medio para llegar a la verdad, la identificación de la justicia con la ley que aparece en el Critón y la valoración del trabajo en textos de Jenofonte ( $M$ emorabilia I, $20 \mathrm{II}, 7$ ), autor que tiene una postura diferente en este sentido. En cuanto a la opción de Sócrates por el gobierno de los mejores, interpretan que el concepto de sabiduría equivale en este caso a la autoconciencia de las propias limitaciones y que, por lo tanto, lo que Sócrates reclama a los políticos es honestidad intelectual e idoneidad.

- Finalmente, podemos incluir una posición ecléctica entre las anteriores, que sostiene que Sócrates es democrático, pero añora la democracia tradicional vivida en su juventud ${ }^{10}$. De este modo, se habría inclinado por un

\footnotetext{
${ }^{7}$ El autor se refiere a los textos de Platón, pero entiendo que se puede aplicar también al caso dejenofonte.

${ }^{8}$ Podemos incluir en esta orientación a: Eggers Lan, 1971: 70-71 y 109-110; a M iguens, 1994: 18-19 y a Da Silveira, 2002: 32.

${ }^{9}$ Adhieren a esta postura: Mondolfo, 1959: 18-20 y M uñoz Valle, 1977: 16-20 y $28-29$.

${ }^{10}$ Sealinean en este modo de ver el tema: Tovar, 1947: 274 y 278; también M ontenegro, 1953: $42,47,48$ y 49.
}

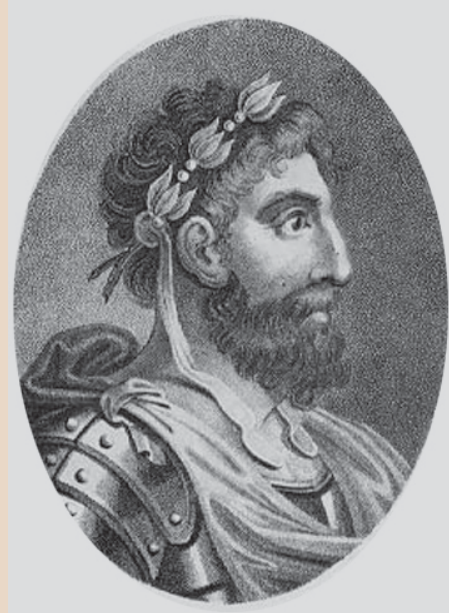

Jenofonte 


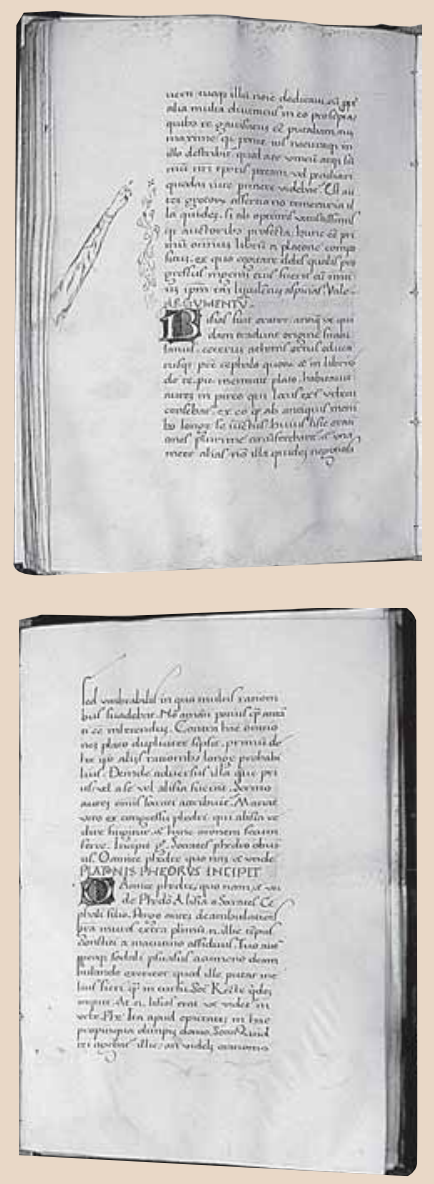

sistema basado en leyes democráticas pero bajo la dirección de una aristocracia de la inteligencia (como con Pericles) que frenase la participación sin límites del pueblo.

Las tres interpretaciones tienen buenos argumentos para sustentar sus planteos. Sin embargo, entiendo que no es en este plano de debate por donde pasa lo central en la actitud política de Sócrates. M ás allá de su adhesión o rechazo a la democracia, en diferentes textos claves puede advertirse que al filósofo le interesa la vida de la polis, o mejor, la buena vida (eudaimonía) de la polis, por sobre cualquier otro tipo de consideraciones. Sirvan como ejemplo los siguientes pasajes:

¿[...] y no lo llamaría buen rey sólo por gobernar bien su propia vida, sino por asegurar también la felicidad de sus súbditos? En efecto, un rey es elegido no para que sepreocupe exclusivamentedesu propio bienestar, sino para que sean felices, gracias a él quienes lo han elegido [...] Examinando de este modo cuál era la virtud de un buen jefe, Sócrates prescindía de cualquier otra y sólo se quedaba con la de hacer felices a las personas que estaban bajo su mando (Jenofonte: M emorabilia III, 2, 2-4).

[Supongamos] que, en vista de eso, me dijeran "Sócrates, Anito no nos persuadirá ahora, sino que te absolvemos, sobre esta [base]: nunca pasarás el tiempo en esta investigación ni en filosofar; pero si eres sorprendido haciéndolo morirás".

Supuesto tal caso, como he hecho, de que se me absolviera sobre tales [bases], les contestaría: Yo los respeto, señores atenienses, y los estimo, pero hedeobedecer al dios antes quea ustedes, y mientras tenga un hálito devida y [ sea] capaz de ello, no cesaré de filosofar, y de exhortarlos a ustedes, y de explicarle a aquel de ustedes que encontrase, diciéndole cosas como las que acostumbro: "Querido amigo, que eres ateniense [esto es], de la ciudad más poderosa y demayor fama en cuanto a sabiduría y fuerza, ¿no te avergüenzas de preocuparte por tu fortuna, de modo de acrecentarla al máximo posible, así como a la reputación y a la honra, mientras no te preocupas ni reflexionas acerca de la sabiduría, de la verdad y del alma, de modo que sea mejor?". Y si alguno de ustedes me disputara y afirmara que él se ocupa [de estas cosas], yo no lo soltaré en segui da y me marcharé, sino que lo interrogaré, lo examinaré, lo refutaré. Y si me parece no estar en posesión de lo que hacea su perfección, se [lo] diré, y le reprocharéque confiera mucho valor a lo que es inferior, y poco [valor] a lo que es superior.

Y haré esto con quien sea que encuentre, sea más joven o más anciano, extranjero o conciudadano, aunque más con mis conciudadanos, desde que metienen más próximo en la sociedad (Platón: A pología deSócrates 29 d-30 a).

La preocupación primordial de Sócrates es la elevación de sus conciudadanosen la virtud a través dela educación, lo que ha llevado a considerárselo 
el padre de la ética política. Esta concepción de la política en tanto plenificación del hombre en la polis nos retrotrae a las raíces griegas del concepto de política y anticipa la definición aristotélica de hombre como zoon politikon (Política 1253 a).

Para Sócrates la ética tenía una fundamentación de tipo religioso dado que, como él mismo nos dice, su vocación por hacer mejor a los polités y por este camino a la polis, tiene su origen en un mandato divino. Esta inclinación espiritual del filósofo será uno de los motivos que lo llevará a la muerte, aunque quizás no baste esta exégesis para comprender las razones de su condena.

\section{EL JUICIO Y LA CONDENA A MUERTE}

Cuando leemos la Apología de Sócrates de Platón o la de Jenofonte nos encontramos con una delicada aporía: se halla presente, y de modo brillante bajo el estilo de Platón, la defensa que Sócrates hace de sí mismo; pero no conservamos el alegato contra el acusado, seguramente pronunciado por Anito. Este hiato debe ser suplido por medio de un trabajo de ingeniería hermenéutica, que permita adquirir una visión amplia e imparcial del juicio a Sócrates.

El dato con el cual contamos de modo seguro, ya quenos es transmitido por fuentes diversas, es la acusación que M eleto, Licón y Anito levantaron contra Sócrates. De acuerdo con la A pología de Sócrates escrita por Platón los términos de la misma fueron los siguientes:

Sócrates, dice, es culpable de corromper a los jóvenes y de no creer en los dioses que la ciudad cree sino en otras [cosas] demoníacas nuevas (24 b).

En las obras de Jenofontela acusación es la misma, aunque es presentada en orden invertido: no creer en los dioses en los que cree la ciudad y corromper a los jóvenes (A pología de Sócrates 10 y M emorabilia I, 1). Además, poseemos el testimonio que, según Diógenes Laercio, aporta Favorino. Este autor del siglo II habría visto en el templo de Cibele el texto original de la acusación, que nos transmite Laercio:

Sócrates quebranta las leyes, negando la existencia de los dioses que la ciudad tiene recibidos, e introduciendo otros nuevos; y obra contra las mismas leyes corrompiendo la juventud. La pena debida es la muerte (libro II, Sócrates).

El contenido dela imputación seenmarcajurídicamentedentro del concepto de asebeia (impiedad) que, originalmente, comprendía delitos como

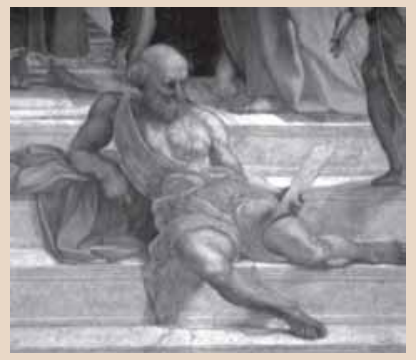

Diógenes 
la destrucción de imágenes de los dioses o la introducción de nuevas divinidades; aunque la noción sufrirá un "considerable ampliación de su esfera" (Gil, 1985: 54) con la ley promovida por Diopiteshacia el 430 a. C. Deacuerdo con este decreto "debían ser denunciados quienes no creyeran en las cosas divinas o dieran explicaciones sobre los fenómenos celestes" (Gil, 1985: 54).

No es casual que la ley haya sido promulgada en momentos en que se iniciaba la Guerra del Peloponeso, conflicto quetrastocó valoresfundamentales de los atenienses y que contribuyó a crear un ambiente de temor y angustia del cual fueron víctimas, sobre todo, los intelectuales innovadores ${ }^{11}$. Cuando Sócrates fue condenado la guerra ya había concluido, pero persistía el clima de incertidumbre descripto. Es más, el recelo se proyectaba ahora hacia el potencial retorno de un gobierno oligárquico como el instaurado después de la derrota ateniense.

¿Existió este temor frentea las ideas de Sócrates en sus acusadores y en el Tribunal quelo condenó? Conocemos el texto de la incriminación y la sentencia final pero, como se ha advertido, nos falta la voz de quienes emprendieron el pleito alegando las razones de su iniciativa. Sin embargo, podemos encontrar una primera pista en la misma denuncia: Sócrates es culpable "de no creer en los dioses en que la ciudad cree". Tenemos aquí un componente marcadamente político en el documento: a Sócrates sele atribuyeir en contra de principios básicos de la polis como son sus dioses. Sucede que en el mundo antiguo, y en la Grecia clásica particularmente, las nociones de política y religión, hoy autónomas, se hallaban estrechamente imbricadas.

Se puede afirmar, entonces, que el enjuiciamiento a Sócrates tuvo un carácter político, al menosen el sentido amplio y primigenio del término. Ahora bien, podemos intentar dar un paso más y preguntarnos si también existió en los jueces el temor dequeSócrates trastocara con sus ideas el statusquo vigente, es decir los cimientos de la recientemente restaurada democracia. En este caso, el interrogante se enmarca dentro de un sentido restringido del concepto de política, que alude estrictamenteal gobierno y a los regímenes políticos.

Un camino, quizás el único, para dilucidar el problema planteado es intentar la reconstrucción de la declaración de Anito durante el juicio. La tarea ha sido llevada a cabo, creo que magistralmente, por Conrado Eggers Lan (1971). Aquí, sigo en líneas generales sus pasos.

Hacia el 393 a. C. ( seis años después dela muerte de Sócrates), Polícrates escribió un panfleto titulado Acusación contra Sócrates. En el mismo, el autor parece retomar la visión que de Sócrates tenían sus querellantes. Si bien

11 "El temor de perder el apoyo de los dioses que consideraban firme desde la guerra contra el persa, pero, más aún, el de perder su imperio y las ventajas de todo tipo que él mismo les proporcionaba, han de haber creado en los atenienses, en todos ellos, un estado psicológico de histeria que vería enemigos en todas partes, especialmente en la clase pensante" (López de Hernández, 1991: 49).
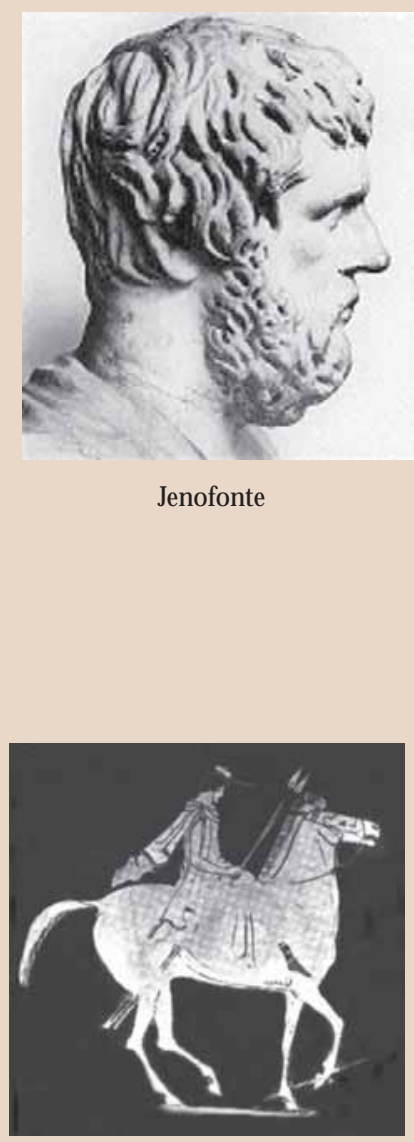
no contamos con el opúsculo, Jenofonte incorpora en M emorabilia las acusaciones de Polícrates a fin de refutarlas ${ }^{12}$. A mi entender, tres son las incriminaciones centrales desdela perspectiva que nos ocupa: en primer lugar, el rechazo hacia el sistema de sorteo; en segundo, el que entre los discípulos de Sócrates hubiese personajes nefastos para Atenas como Alcibíades y C ritias; por último, el desprecio de Sócrates hacia el pueblo. Conviene citar los textos aludidos a fin de apreciar claramente los ataques a Sócrates y la réplica deJenofonte:

Pero, ipor Zeus!, decía su acusador, Sócrates inducía a sus discípulos a despreciar las leyes establecidas, cuando afirmaba que era estúpido nombrar a los magistrados de la ciudad por el sistema de haba, siendo así que nadie querría emplear un piloto elegido por sorteo, ni un constructor, ni un flautista, ni a cualquier otro artesano, a pesar de que los errores cometidos por ellos hacen mucho menos daño que los fallos en el gobierno de la ciudad. Tales argumentos, afirmaba el acusador, impulsan a los jóvenes a despreciar la constitución establecida y los hacen violentos. Yo, en cambio, opino que los que practican la prudencia y se consideran capaces de dar enseñanzas útiles a los ciudadanos son los que resultan menos violentos, porque saben que las enemistades y los peligros son propios de la violencia, mientras que con la persuasión se consiguen las mismas cosas sin peligro y con amistad [...] (I, 2. 9-11).

Pero, decía su acusador, al menos dos contertulios quetuvo Sócrates, Critias y Alcibíades, hicieron muchísimo daño a la ciudad. Pues Critias fue el más ladrón y violento de cuantos ocuparon el poder dela oligarquía, yAlcibíades, por su parte, fue el más disoluto einsolente de los de la democracia. Por mi parte, no voy a defenderles, si estos dos hicieron al gún daño a la ciudad, pero explicarésu relación con Sócrates tal como ocurrió. Estos dos hombres fueron por naturaleza los más ambiciosos de todos los atenienses, querían que todo se hiciera por mediación de ellos y llegar a ser más famosos que nadie [...] (I, 2. 12-14).

De Homero afirmaba el acusador que Sócrates citaba con frecuencia aquel pasaje en el que muestra cómo Ulises

"Cada vez que encontraba a un rey y a un hombre distinguido, colocado ante él lo detenía con palabras suaves:

Ilustre, no está bien que sientas miedo como un cobarde, Antes bien, siéntate y haz que los pueblos se sienten.

Pero cuando veía a un hombre del pueblo y lo encontraba gritando, golpeábale con el cetro y le increpaba con palabras:

¡D esdichado!, siéntate en silencio y escucha las palabras de otros

12 "El motivo determinantedeacaso toda su literatura socrática [la de]enofonte] es el discurso de acusación que publicó el rétor Polícrates hacia el 393" (Tovar, 1947: 32). 
que son más poderosos que tú. Tú eres pacífico y débil,

no cuentas en la guerra ni en el consejo".

Decía que explicaba este pasaje dando a entender que el poeta elogiaba el que se gol peara a los hombres pobres del pueblo. Pero Sócrates no quería decir tal cosa, porque en otro caso habría pensado que él mismo debía ser golpeado. Decía más bien que las personas que no son útiles ni de palabra ni de obra, incapaces de ayudar al ejército, a la ciudad y al propio pueblo en caso necesario, sobre todo si encima son atrevidos, deben ser castigados por todos los medios por muy ricos que sean. Sócrates, por el contrario, era evidentemente un hombre popular y amigable, pues a pesar de tener numerosos discípulos, extranjeros y ciudadanos, nunca sacó dinero de ese trato $[\ldots](I, 2.58,60)$.

H ay un dato queno puede pasar desapercibido en los pasajes transcriptos: Jenofonte se preocupa por rebatir a Polícrates la segunda acusación (el tema de los discípulos funestos para Atenas) y la tercera (el desprecio por el pueblo) pero no el rechazo de Sócrates hacia el régimen de sorteo. La réplica de Jenofonte alude sólo a la consecuencia (hacer violentos a los jóvenes) que traeesterechazo. El silencio de en ofonte parece reflejar la reserva deSócrates hacia el sistema de sorteo ${ }^{13}$ y hace comprensible la crítica de Polícrates en este sentido. A su vez, la censura de Polícrates estaría poniendo de manifiesto el temor que algunos atenienses habrían tenido hacia la actitud política deSócrates en el momento del juicio.

Podría lícitamente cuestionarse el vínculo existente entre los reproches de Polícrates a Sócrates y la exposición de Anito en el proceso del 399. La pregunta es la siguiente: ireitera el texto de Polícrates las imputaciones de Anito? Pienso que puede encontrarse la respuesta apelando a un diálogo intertextual, como hace Eggers Lan. Este autor señala que resulta sugestivo que en su A pología Platón presente a Sócrates defendiéndose de cargos que no aparecen en la acusación escrita: jamás ha actuado contra las leyes ( 32 b33a), no se le puede reprochar sobre la conducta de quienes han dialogado con él ( 33 a) y ha tratado tanto con ricos como con pobres sin distinción ( 33 a-b) (Eggers Lan, 1971: 24-25). Es decir, Sócrates se defiende de las mismas denuncias formuladas por Polícrates.

Los críticos coinciden en anteponer la fecha de la Apología de Platón al documento de Polícrates ${ }^{14}$. Por lo tanto, Sócrates responde, sin dudas, a consideraciones que debió exponer Anito y que luego fueron retomadas por Polícrates en su Acusación contra Sócrates.

${ }^{13}$ Reparo que puede confirmarse si tenemos en cuenta otros textos. Ver por ejemplo Platón: Critón 4 a-d.

${ }^{14} \mathrm{~A}$ pol ogía de Sócrates habría sido escrita por Platón poco después de la muerte de su maestro. Ver Noussan Lettry, 1988: 21.

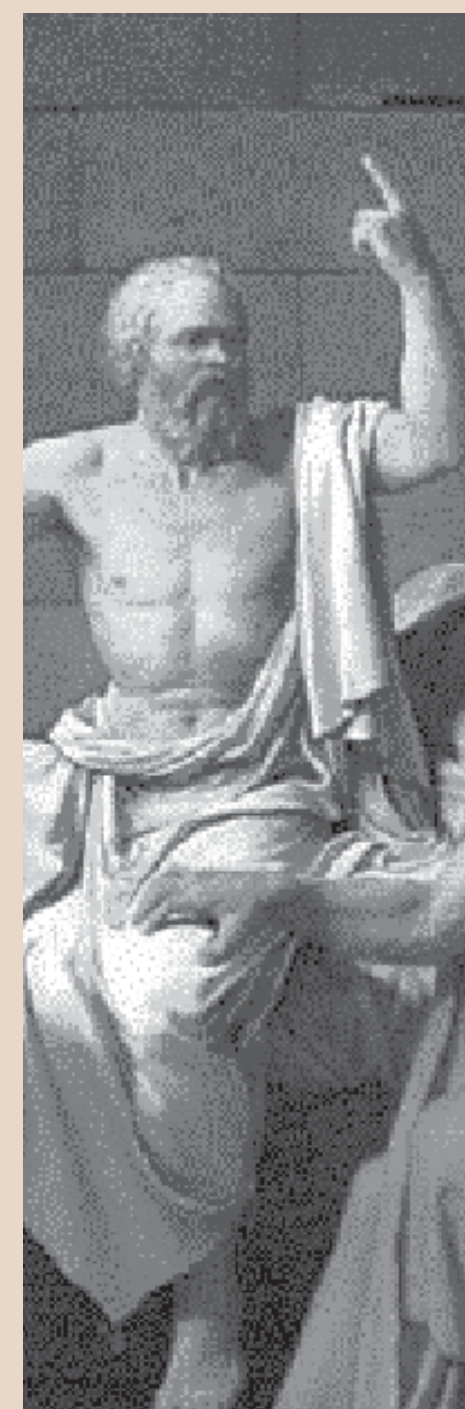

$67 \quad$ Atenea 491 


\section{CONCLUSIONES}

Resulta sumamente difícil discernir cuál era la opinión de Sócrates sobre la democracia ateniense. He presentado, sintéticamente, algunas posiciones interpretativas al respecto. Si compulsamos los testimonios de Platón y Jenofonte, debemos arribar a la conclusión de que Sócrates se oponía al sistema de sorteo y pretendía que fuesen los más capaces quienes dirigiesen los asuntos públicos (idea que Platón llevó a sus últimas consecuencias en La República). Sin embargo, no podemos en este caso cumplimentar el segundo requisito metodológico sugerido en este trabajo (atribuir a Sócrates las ideas contrapuestas a las del autor de la fuente), ya que tanto Platón como Jenofonte desdeñan la democracia. Por lo tanto, y de acuerdo con la terminología platónica, creo queel tema se halla en el campo dela doxa (opinión) y no en el de la episteme (ciencia).

Sin embargo, sí podemos conocer la opinión que sobre la actitud política de Sócrates tenían sus acusadores y jueces. Sin duda, algunos líderes democráticos del momento como Anito, veían en las enseñanzas del filósofo una amenaza para el régimen. Tras la acusación de asebeia, que como hemos visto tiene una carga política en sí misma, se vislumbra un claro temor sobre el peligro que, según la visión de los litigantes, suponía el magisterio socrático para la democracia ateniense.

Por último, creo conveniente retomar la primera proposición del estudio, donde planteo que la condena a muerte de Sócrates cuestiona la libertad de pensamiento y de expresión presentada por el Epitafio de Pericles. Para comprender este suceso histórico debemos ubicarlo en el contexto correspondiente. Las instituciones democráticas de 399 a. C. son las mismas que en 430 a. C. (año del discurso de Pericles) pero la situación psicológica es diferente. Pericles tiene tras de sí una tradición democrática consolidada por años de vigencia, mientras que en el 399 a. C. Ia democracia conserva vivas las heridas del régimen tiránico del $404 \mathrm{a}$. C. y ve con resquemor todo atisbo de reinstauración del mismo.

\section{REFERENCIAS BIBLIOGRAFICAS}

\section{FUENTES DOCUM ENTALES}

Aristóteles. 1951. Política. M adrid: España, Instituto de Estudios Políticos. Traducción de María Araujo y Julián Marías.

Platón. 1997. Diálogos. Madrid: Gredos. Traducción de J. Calonge Ruiz, E. Lledó Iñigo y C. García Gual.

Platón. 1971. Apología de Sócrates. Buenos Aires: Eudeba. Traducción de Conrado Eggers Lan. 
Diógenes Laercio. 1947. Vidas, opiniones y sentencias de los filósofos más ilustres. Buenos Aires: El Ateneo. Traducción de José Ortiz y Sanz.

Tucídides. 1969. Historia de la guerra del Peloponeso. Madrid: Editorial Hernando. Traducción de Francisco Rodríguez Adrados.

Plutarco. 1964. Vidas paralelas, Alejandro y César. Biógrafos griegos. M adrid: Aguilar. Traducción de Antonio Sanz Romanillos.

Platón. 1970. Las Cartas. Madrid: Instituto de Estudios Políticos. Traducción de Margarita Toranzo.

\section{BiBLIOGRAFÍA}

Bergson, Enrique.1939. La risa. Ensayo sobre la significación de lo cómico. Buenos Aires: Prometeo.

Da Silveira, Pablo. 2002. Historia de filósofos. Buenos Aires: Punto de Lectura.

Eggers Lan, Conrado. 1971. "Estudio preliminar" a Platón. Apología de Sócrates. Buenos Aires: Eudeba.

Gil, Luis. 1985. Censura en el mundo antiguo. Madrid: Alianza.

López de Hernández, Nelly. 1991: “D emocracia antigua”, en Revista deH istoria Universal 4, pp. 25-50.

Miguens, José Enrique. 1994. Política sin pueblo. Platón y la conspiración antidemocrática. Buenos Aires: Emecé.

M ondolfo, Rodolfo. 1959. Sócrates. Buenos Aires: Eudeba.

M ontenegro, A. 1953. "El tradicionalismo político de Sócrates", en Revista de Estudios Políticos 72, pp. 37-64.

Noussan Lettry, Luis. 1988. "Introducción" a: Platón. Apología de Sócrates. Buenos Aires: Astrea.

Muñoz Valle, Isidoro. 1977. "Actitud de Sócrates ante la democracia ateniense", en Estudios Filosóficos 71-72, pp. 9-21.

Ramis, Juan Pablo. 2003. "El humor en la Atenas clásica”, en: García de Yaciófano, Adriana. Historias de la historia IV. La vida cotidiana. Mendoza: Facultad de Filosofía y Letras, Universidad Nacional de Cuyo.

Rosen, Klaus. 1999. II pensiero politico dell'antichità. Bologna: II Mulino.

Sauvage, M icheline. 1963. Sócrates y la conciencia del hombre. Madrid: Aguilar.

Tovar, Antonio. 1947. Vida de Sócrates. M adrid: Revista de O ccidente.

Vanoyeke, Violaine. 2000. Pericles. M adrid: Alderabán Ediciones. 